\title{
Secrets and lies: Narrative methods at the limits of research
}

\section{Keywords \\ Creolization \\ diaspora \\ hybridity \\ methods \\ narrative \\ oral history}

\begin{abstract}
This collaborative article explores some commonalities to be found in narrative methods used by Caribbeanist, Joan Anim-Addo and sociologist, Yasmin Gunaratnam. Recognizing how narratize and stories 1 are socially inflected and relational, our work with diasporic stories approaches narrative as an unstable and evolving event that poses its own ethical provocations. We discuss the limits of our respective methods - oral history and biographical narrative interviews - through an exploration of 'secrets and lies' in the telling and relaying of stories. We consider, centrally, the relations between facts and fictions in diasporic stories, highlighting two central conundrums that we have encountered in our research: (i) what is experienced and lived but cannot be said/told; (ii) what is told but not necessarily lived. Creolization theory and notions of cultural hybridity serve to frame the conversation that we engage.

Writers imagine that they cull stories from the world. I'm beginning to believe that vanity makes them think so. That it's actually the other way around. Stories cull writers from the
\end{abstract}


$$
18
$$

$$
18
$$

19. Working with secrets and dissimulation in diasporic stories we consider, centrally, how narra-

20. tives can be shaped and constrained by social and historical forces: slavery, plantation and

21. colonialism (JA); and internal hierarchies of oppression (YG). We highlight two critical conundrums

22. and how we have each worked with these concerns in our research: (i) what is experienced and lived

23. but cannot be said/told; (ii) what is told but not necessarily lived. Creolization theory (Glissant 1997)

24. and notions of cultural hybridity (Bhabha 1994) frame the conversation that we engage.

25.

26.

\section{Engaging tales of family life}

28. The first chapter of my (JA) 'A Brief History of Juliana "Lily" Mulzac of Grenada and the

29. Grenadines' (Anim-Addo 2007b) was the outcome of a collaborative research project within which

30. I happily agreed to investigate dimly recollected claims by my deceased grandmother that she had

31. Scottish connections. ${ }^{1}$ I use the word 'happily' because before me laid the welcome prospect of oral

32. history methods that I had successfully deployed since publication of Longest Journey: A History of

33. Black Lewisham (Joan Anim-Addo, 1995). In addition, researching Juliana's 'history' offered another

34. opportunity to write about my grandmother with whom I had specific and especially strong

35. narrative bonds, those of storytelling within an oral Creole culture. ${ }^{2}$ At the same time, while Longest

36. Journey represented a public project, that of presenting a history of a group appearing within

1 The publication outcome of the project became published as Caribbean-Scottish Relations: Colonial \& Contemporary Inscriptions in History, Language \& Literature (Joan Anim-Addo, 2007b).

2 I had written about her before. See the poetry collection Haunted by History (Joan 1996). 
mainstream Britain to be historyless, Juliana's possible Scottish 'connection' seemed at the outset a 1. much more personal and speculative undertaking.

Proving to be considerably more troublesome than anticipated, Juliana's 'Brief History' challenged and resisted archival methods, from worm eaten record books, musty boxes piled high in old rectory rooms, hurricane-damaged libraries and partially digitalized systems in the Caribbean to state 5. of the art national archives in the West. No documented evidence could be found of her existence.

Although I had pinned my hopes on archival sources first and foremost, perhaps a baptismal record, a birth certificate, or such like, nothing could be found though I searched the record offices of three islands. I appeared to have reached the limits of archival research for substantiating this strand of subaltern Creole history. Yet, my grandmother's story had thoroughly 'culled' me.

When she died, 22 October 1969, I was in London. I had promised her that she would see me soon, for she had spoken her fears that she would not. However, she was proved right. Having just visited, we could not afford to return. I, devastated, had nothing of hers to pin my memories upon except a photo that I had taken on my visit. Angry, doubtless bewildered, eventually I had tried to shake her off, to rid myself finally of the burden of resolving my two selves: who I had been in the home we shared with her in Grenada, and who I was in London. The two selves were not only a chasm apart. Increasingly, my island home, or rather, the space that my family had owned - acres of green where I stumbled through corn wands or sweet potato slips or picked peas, or watched cows and sheep graze ever since childhood receded into greyness, and made no sense in relation to the impossibility of our living circumstances in London.

Too numb to grieve her senseless dying before my return, I tried to forget. When I did return, the empty space where she once sat in her rocking chair on the verandah remained accusingly empty. The chair still rocked. I set it rocking but her form did not fill it. It remained empty. I looked over the pasture from her verandah. The same cows seemed to stand munching in a backdrop of green. The same coconut branches seemed to be waving in the distance.

With time, the house once full of children and grandchildren grew steadily quiet. The wooden structure fell into disrepair. On another visit, there was a new building. The home space of intimacy with her had irrevocably gone. Her living room where she sewed, where a picture of Carmen Miranda hung on the wall, her bedroom with its sea mementoes and its huge bed that seemed an ocean, her back door and stairs on which we played, all had gone. Though I consoled myself, forgot, grew up, covered an emptiness with running around, trying this and that, years later when I became determined to write, she intervened. We drew a truce. I accepted her as muse. I wrote. A sheaf of poems in Haunted by History (1996) bore witness to my reclaiming our reconnection. But who was she other than an adored grandmother?

Strangers and those not quite her equals in the scheme of things had called her 'Mistress Simmons', reinforcing daily her ties to her husband. Why I understood that she knew herself to be 
1. someone in her own right will never be clear, tied as it is to a child's memory. I do not recall by what

2. process she had impressed upon me some of the significance attached to the name Mulzac but this

3. 'private' narrative had 'colonized' me. Now, the only possible source between abandoning the project

4. and the possibility of Juliana's 'Brief History' appeared to be the oral, which, in its familiar and

5. circuitous manner, its fits and starts of revelation and confirmation, led back to two sites: the island of

6. Juliana's birth, Union Island, and a more southern island, Carriacou, where she was later married.

7. A certain shock of discovery that we refer to in this conversation as 'secrets and lies' began to

8. further unravel itself as, following the trail laid by Annie, Juliana's eldest daughter, I found more

9. than the evidence I sought in a 'Certificate of Marriage', bound and boxed in an abandoned archive

10. in the rectory of Christchurch, Carriacou. I discovered that Juliana was the daughter of a Scot

11. celebrated on Union Island. Moreover, although her father, Charles Mulzac, officially had only four

12. children within wedlock, many more 'outside' daughters would come to light through the oral

13. accounts that I engaged. Compounding the concern that grew, I began to appreciate that, like

14. Juliana, several of her sisters were born in the years when the patriarch's legitimate children were

15. producing grandchildren. It seemed that the island's famous Scot, having secured his leasehold for

16. the island from the family of the Bristol slave-trading family of Samuel Span, had continued the

17. many exploitative practices of slavery, including, the everyday sexual exploitation of the island's

18. women. Furthermore, this troubling practice took place in the post-Emancipation years when the

19. islanders might legally have expected conditions qualitatively different from those of chattel

20. slavery.

21. I have, rather, privileged scholarly concern with interpretation despite the promise to focus on 22. narrative method. Yet, as Joan Schwartz and Terry Cook remind us:

23.

24. Like archives collectively, the individual document is not just a bearer of historical content,

25. but also a reflection of the needs and desires of its creator, the purpose(s) for creation, the 26. audiences viewing the record, the broader legal, technical, organizational, social, and cultural-

27. intellectual contexts in which the creator and audience operated and in which the document

28. is made meaningful, and the initial intervention and on-going mediation of archivists.

31. Complicating the personal dimension of the research, the affects and intersubjectivity informing

32. the research (see YG, below), an important part of the Creole cultural context is to be understood

33. in that Juliana's is a family story within a culture permeated by orality. This further complicates

34. narrative methodology for the hopeful biographer, especially since, in this instance, the interviewer

35. functioned as both niece and determined biographer who must manage aging relatives, themselves

36. uncertain of both expertise and the nature of the scholarly exercise itself. 
In the light of this, I conducted no taped interviews with family members since, knowing the 1. oral culture thoroughly, I gauged that in order to access information that elders held, I would have 2 to re-stimulate well-established cultural patterns, namely the telling of family stories. I underscore 3 the notion of re-stimulation since my memory of storytelling related to childhood and decades earlier. Much had changed including widespread displacement by television soap operas of family storytelling traditions as everyday cultural practice. I therefore presented myself as one who was ever curious to gather information for yet another part of my grandmother's story. Whenever I appeared, I would ask questions and invite the sharing of memories for as long as the elder was willing to do so. In the circumstances, I assessed that presenting a tape recorder would render the remembering too formal and would inhibit the narratives I sought. Rather, generational exchange in familiar oral tradition was replicated, albeit with pen and paper always at hand 'in case I forget'. By this means, visits to Auntie Annie yielded information about her mother's growing up, marriage in Carriacou, the sisters who visited her, and so on. The stories would then be corroborated through further family story time, primarily with an uncle and my mother. In these sessions I could test versions of Juiana's story as I shaped them, a process that offered fruitful opportunities for corrections. One such version became the poem, 'Family History', an extract of which follows:

[.] Juliana, Born in Union island, 1889,

was daughter of Annie Robertson, mother of boys: Hugh, John and Lammie, the story goes,

and Juliana's three sisters: Princess, Louisa and

Sue-noon. But who was brother and sister?

And who was half? These things not marked .

Annie, who they tell us, never left Union,

dying early, her daughter, Juliana, travelled

to Carriacou to live with her godmother,

Mammie Jones - is how they called her -

who kept Juliana until marriage

and the move to Grenada.

$\begin{array}{ll} & 17 . \\ & 18 . \\ & 19 . \\ 20 . & 21 . \\ & 22 . \\ & 23 . \\ & 24 . \\ & 25 . \\ & 26 . \\ & 27 . \\ & 28 . \\ & 29 . \\ \text { (Anim-Addo 2006: 38) } & 30 . \\ & 31 . \\ & 32 . \\ & 33 . \\ \text { ion offered in the first } & 34 . \\ \text { stated. In addition, } & 35 . \\ \text { rsisted as stated in the } & 36 .\end{array}$


1. point irrevocably to the truth? Although the questions remained, especially in the absence of

2. documented records, it had begun to fall in place that Juliana's first daughter, Annie, had been

3. named after her grandmother, Annie, whom she had never seen since she had 'died young', as

4. brothers and sisters all reported. Furthermore, there was discernible reported distress in Annie's

5. comments, as I wrote them down, that her mother had been forced to 'work like a jackass as [an]

6. outside child'. For this reason, 'Godfather [Hubert Jones] decided to take her'. ${ }^{3}$ The 'taking' or

7. 'shifting' of a child from one set of domestic circumstances to another became a familiar child

8. rearing practice commonplace during the period of Atlantic slavery and its aftermath.

9. In oral cultures such as ours, a key member of the family used to be relied upon to remember

10. and pass on details of family history. Juliana's eldest daughter, Annie, also known as Elue,

11. assumed that role for several decades after her parents' death. Family history was continually

12. referred to and verified by her. When in doubt, one was always sent to 'ask Elue. She will know'.

13. As family historian, she was adamant that her parents had married in 1910. She contextualized

14. the date thus: 'Mammie always said it was 1910. I think it was September but that I don't recall,

15. now. But it was definitely 1910'. When she was interviewed for the purposes of this research she

16. was 90 years old. At times, frustrated by the loss of her ability to recall family details at will, she

17. remonstrated:

18.

19. You should have asked me those questions last year or even last month when I was a little

20. better. I can't remember anything again.

21.

22. Indeed, the certainty had gone from much of the detail she offered. Asked for the name of her

23. grandfather, she replied, 'Charles, I think'. To the question: 'Was he Charles or Richard?' she

24. faltered and declared herself unsure. At the same time, she remained adamant that she remem-

25. bered visiting Union Island with her mother on the occasion of her grandfather's death. This, I

26. calculated, could not have been possible since he had died in 1893, well before her birth, more

27. than two decades later. So, who was Annie remembering as her grandfather? Was it her mother's

28. surrogate father? Within such conundrums lies the weakness of the oral when the body is literally

29. the archive, representing a differentiated 'dwelling' from that of Antoinette Burton's Dwelling in the

30. Archive (2003), as I elaborate in 'I-Daughter'.

31. Meanwhile, our subject, daughter of the Scottish colonial entrepreneur, Juliana could neither

32. read nor write. Moreover, her mother having 'died young' suggests that she was a young girl, even

33. for those times, in the latter decades of the nineteenth century. In any event, Juliana was raised an

34. orphan. Her father's grandson, her nephew, Hugh Mulzac, three years older than she was, would

35. write of the islanders of the era:
3 This practice survived from slavery and is referred to as 'child shifting' or 'othermothering'. See'Othermothering' (Collins 1991). 
All 5,000, save one, were of African origin, the descendants of slaves captured, bound and 1. carried across the ocean in the centuries-long slave trade between the West Coast of Africa the West Indies, and the eastern shores of the United States. Their forefathers' lives had been a hell on earth, and they, 'emancipated,' had achieved a kind of purgatory.

(1963, emphasis added) 5

When Hugh wrote his memoirs in which he referred to his grandfather's four children, was he aware 7 . that there were many more siblings outside of wedlock, and that he had aunts whose ages were similar to his own? Indeed, it shocked my sensibilities to find that Juliana, born in 1889, had a three years old nephew, Hugh, who was her father's grandson. Whether anyone among my respondents understood these family secrets, I have been unable to ascertain. No one stressed the significance, and the concerns I raised were met with a momentary chuckle, a 'well in those days' and a moving on of the conversation. But what do such secrets and lies mean in such a colonial context?

The second chapter of 'Brief history', completed as 'I-Daughter' for Within and Without Empire (Carla Sassi and Theo van Heijnsbergen, forthcoming) insisted on a focus on Juliana's (also known as Lily) 'Brief History' 'in relation', as Edouard Glissant's theoretical writing has urged, to Scottish imperial networks, and the absence of women, particularly family members. Since family stories had led me to the discovery of a network of 'outside' or illegitimate daughters of the Scottish entrepreneur, it seemed important to begin to situate them in relation to a system of concubinage that produced family by powerful white fathers who could choose the degree of responsibility with which they acknowledged, supported or ignored their children by black mothers. So, another colonial family secret is that white colonial fathers systematically instilled patterns of paternal irresponsibility and familial instability, through slave laws and the infrastructure of Atlantic slavery, and continued the practice, where possible, following the Emancipation of enslaved Africans in the region. Two considerations arising from this practice might usefully be highlighted: the Caribbean male as absent father, and familial 'disassociation' or dysfunction, both of which continue to trouble the present. Later generations of Caribbean families, and particularly Caribbean men would be charged with familial irresponsibility, and the women, correspondingly, with being 'too strong'.

\section{Diasporic dying}

My (YG) interest in diasporic dying began in 1992 following the deaths of my parents, first generation migrants from Sri Lanka (Tamil and Singhalese), who died within six months of each other. Questions of genealogy and of belonging - questions that have dogged me all my life - crowded in on me. In my grief I searched for anything that had been written about migrants and death, dying and bereavement. I found little. My doctoral research, an ethnographic study of a 
1. London Hospice emerged some years later. With hindsight it was a work of mourning undoubt-

2. edly, but I also wanted to know more about our lives as migrants and how our biographies connected us to others (or not). The work of mourning is always searching work.

The interview with 'James' that I discuss here was part of this ethnographic research, where 5. I interviewed migrants mainly from the Caribbean, South Asia and Africa (see Gunaratnam 2003). James, a refugee from Kenya, was a disease impostor. He was dying from HIV-related conditions

7. but was passing himself off as a cancer patient to protect his family from stigmatization. In making 8. sense of James's stories I have drawn upon Homi Bhabha's account of colonial cultural relations

9. and communication, where "The meaning of an utterance is quite literally neither the one or the

10. other' (1994: 53), installing opportunities for cultural symbols to be 'appropriated, translated,

11. rehistoricized and read anew' (1994: 55). The simultaneous possibilities that cultural codes may be

12. repeated, adapted or twisted in practices of mimicry and 'sly civility' is theorized by Bhabha as

13. subverting cultural authority 'so that mimicry is at once resemblance and menace' (1994: 123).

\section{A mimic man}

James did not want anyone, including his estranged wife and two children - whom he lived with - to know that he had AIDS 'I just thought that the moment I mention this kind of thing, the whole family is going to shatter'. James was diagnosed as HIV positive after noticing a thrush infection in his mouth.

19. He thinks that he probably contracted the virus about four years before he took the HIV antibody test.

21.

22.

How did you feel?

I think the person I saw was quite nice, but it's such a horrifying experience being told that [...] yeah, I, I didn't know what to do [...] with myself or [...] whether to actually scream or cry or what. It was a terrible experience [...] because, you know, you are there, you are alone and here you are presented with this massive answer [...] which you didn't even want to know [...] and that's it. I just sort of froze [...].... I just thought 'It can't be me.'

29. To freeze like this is to be in the lure of simultaneous and opposing affective and chemical

30. impulses. From the early immobilization of shock, there was a movement from thinking 'It can't be

31. me' to a resolve of 'It will not be me'. This leaving behind of a self who is somehow caught-up and

32. at the same time is in flight was a figuration that also appeared in James's migration story. Twenty

33. or so years before I interviewed him, James had left Kenya in pursuit of a better life. Ultimately he

34. says, he found himself stuck in 'a situation whereby you don't have enough money and yet you

35. can't progress yourself, you cannot do anything to progress because you are trying to make money

36. to survive. So things just stay there'. 
To a young man from Kenya the magnetic pull of the 'countries of dreams' was the promise and 1 . the contagion of Anglo-American capitalism. Now, at the end of his life, James was beginning to wonder if he did the right thing in leaving Kenya. He felt that he had little to show for his aspirations or for his serial reinventions as a would-be business manager, warehouse stock controller, community 4 worker and property developer. As he looked back over his life and as he tried to maintain the fraudulent identity of a cancer patient, HIV and its bodily devastation seemed like the least of James's problems. Mostly, he said, he felt hemmed-in by the cultural prohibitions that surrounded his disease.

James kept his distance from the Kenyan community in London - 'With this disease they tend to actually prey on you' - denouncing the community's ignorance and bigotry. At the same time he spoke of how proud he was to be a Kenyan, how he still regarded Kenya as his home,

I still love it. I am going to go back, even if I am dead.

Can you tell me something about that?

I think it's just that I feel that I belong there, and I think that's a general consensus of most of us. We feel that we have no place here, that every person who is able must be taken back, buried back.

The playing out of the fantasy of the burial of a proud Kenyan unblemished by HIV was in reality made impossible because of the medical surveillance and administration that is needed to repatriate bodies with HIV infection. At the time of James's death several African countries were also refusing to receive the body of a person with HIV. In other words, James's post-death extension of mimicry was undermined by medical requirements and the biopolitical threat that HIV bodies (even when dead) were seen to pose to the normative health of a nation. In his essay on 'Sly civility' Homi Bhabha alerts us to the unsettled root of the word territory: '... "territory" derives from both terra (earth) and terrere (to frighten), whence territorium, "a place from which people are frightened off"' (2004: 142, original emphasis).

\section{Body heat}

One does not have to subscribe to a particular methodology or to a discipline to recognize how narratives and stories can be shaped by the social and the relationships between the narrator and the listener. A critical point highlighted by feminist theorists is the importance of recognizing how our research and knowledge practices are 'situated' (Haraway 1988), producing necessarily partial accounts. And in every research context, whether in an interview or in the archive we are affected: moved, changed, transformed. Attentiveness to these dynamics in practices of 'reflexivity' involves 
1. a critical stance to research methods and to knowledge making practices, seeking to make more . explicit how we produce what we come to know.

Reflexive practice also strives to investigate how the researcher is a part of the production of narratives. 'The investigator's emotions are highly relevant to conversations about ethics'

C. Riessman writes 'because emotions do moral work: they embody judgments about

value'(2005: 473). Practices that support critical reflection in biographical narrative research include the use of field notes in analysis that record interview dynamics and how things feel

8. (see Wengraf 2001); regular fieldwork supervision sessions that help to interrogate research

9. relationships and provide a space where researchers can bring their own 'troubles'; and group

10. analysis of data to encourage diverse perspectives.

11. Yet no matter how rigorous our research methods and practices are, narrative analysis is always 12. partial and provisional. It is this recognition that brings me to narrative as an ethical event. The 13. psychologist Stephen Frosh (2007) contends that experience always exceeds narrative (and, of 14. course, vice versa), not only because experience is itself multifarious and multi-sensual and there

15. are many ways of narrating the same events, but also because to narrate something is to change it.

16. And to change it in relation to an-Other. Using the insights of the feminist philosopher, Judith

17. Butler, Frosh writes,

18.

19. The speaking of the thing acts as a wager, a point at which something is risked into exist20. ence; the very act of doing that ... means that it is worked on in the presence of the

21. Other ... This is, as it happens, exactly the paradigm of relational thinking: as Butler (2004)

22. puts it, "To ask for recognition, or to offer it, is precisely not to ask for recognition for what

23. one already is. It is to solicit a becoming, to instigate a transformation, to petition the future 24. always in relation to the Other' (p. 25).

For Frosh, one way of preserving the multiplicity and relationality of narratives is to pursue an

28. analysis that holds on to 'disrupting and disorganizing' interpretations; analysis that refuses the

29. drive towards the cleaning-up and pulling-together impulses of the researcher in seeking out

30. unifying story-line/s. In my experience, the disruption and disorganization of narratives in face-to-

31. face interviews also plays out in bodily exchanges, a sensuality that is potent in its disruptions but

32. is difficult to express and to theorize.

33. During my interview with James I became caught up in his anxiety and nervousness. I felt

34. small rushes of adrenalin and pinpoints of heat igniting in my face as we moved towards and

35. then around incriminating words and topics. At the same time, James's use of deflection and

36. 
omission - we talked about his 'illness', 'the disease', 'the terminal condition' - made a mockery of 1. my assurances of confidentiality and anonymity. The indeterminacy of words and our nervous interactions in the interview taught me about my limited understanding of the temporal threat of 3. recorded stories. James's cautious storying took account of the immediate dangers of the interview, 4. but also of a possible danger from others in the future who may encounter him through my research.

Although James often chose to talk in the third person and adopted a passive voice, erasing the pronominal I, he was not entirely silenced. Amidst the ordinary conversational moves and turn taking, the densities of silence, hesitation, retraction and innuendo that circulated in the interview were spooky and provocative, sensitized to the indeterminacy of what is made public and 10. what is withheld; what is safe and what is risky. I now think of the heat and pulses of adrenalin 11. that I felt when listening and talking to James as fleshy text messages, small bodily interruptions and abbreviated inscriptions that forced me to feel how even the most ordinary and basic of human exchanges can become potentially catastrophic and life-threatening.

And so James's muted story, with its omissions, stuttering and slinky U-turns, reproduced something of the effects and affects of dys-ease in his life. But complicated questions remain about the ethics and politics of the debilitated mimic and how we might work with fractured, almost-narratives and their sensual effusions.

These artful dodgers can be cultural crowd pleasers as much as radical dissenters. By faking or substituting an identity they shore up normativity and flick the middle finger to the panoptic gaze of biopolitical surveillance, in which social research is also implicated. And in the midst of such ambiguities, there is a lesser elaborated side to sly civility and dissimulation that I have found myself considering: how imposture as a deferral of a stigmatized, endangered identity might occasion its own palliative care; an intervention in suffering that provides pain relief. And not only in the present and for the subject, but also for those in an unknown, but anticipated future.

The word 'palliative' is derived from the Latin noun pallium. There is some tension and play in its meaning: to cover, protect or to cloak.

\section{And now}

As others have recognized there is a certain loss of innocence in working with narrative and stories because narratives are always enmeshed in regulatory networks of power. Narratives are never transparent representations of experience. However, diasporic and biographical stories are especially intruded upon by other spaces and times, so that analysis must become cartographic, excavating 
1. and following how stories are produced and have effects across time and space. With regard to

2. postcoloniality and globalization, the anthropologist James Clifford advocates that researchers,

10. In reflecting upon our work with diasporic narratives we would like to highlight two particular

11. challenges. The challenge for Joan was to move beyond the personal to the historical, and in the

12. process to name things that had been erased or repressed. While the practice of poetry had, in

13. many respects, made available other channels for reflexive methods of dealing with such affective

14. concerns, the realities of racial and sexual oppression, a consideration of rape of a young girl and

15. the possibility of her death in child-birth, all in one's own family, provoked a level of dys-ease that

16. I found, as I have reiterated, deeply 'shocking'.

17. For Yasmin attentiveness to sensuality and affect in the telling of stories allowed new insights

18. into lived predicaments but also constrained understanding. Yet, in her first attempts at making

19. sense of James's narratives, potent contexts went missing as she became focused on the interview:

20. African masks that vanquish demons (Lommel 1966); the trickster tradition of mimicry and

21. dissimulation in Kenya as a response to national regimes of repression signified in the work of

22. Kenyan writers such Francis Imbuga, John Ruganda, Ngugi wa Thiongo and Wahome Mutahi, and

23. whole swathes of British colonial secrecy and mimicry that have sought to cover-up the sanction-

24. ing of torture, castration and rape in Kenya during the Mau-Mau uprisings between 1952 and

25. 1960. There is never only one secret.

26. That our stories, which insisted upon being told, also render the borders between private and

27. public discourse porous is important to this discussion. That they afford some presence to margin-

28. alized stories is key to our intentions. Importantly, also, for us, they assist the dialogic process of

29. methodology that remains as contested and as valuable as ever to the production of knowledge.

30.

\section{References}

32.

33.

34.

35. - (2007a), Touching the Body: History, Language \& African-Caribbean Women's Writing, London:

36. Mango Publishing. 
_ (2007b), 'A brief history of Juliana "Lily" Mulzac of Union Island, Carriacou and Grenada: Creole family patterns and Scottish disassociation', in Giovanna Covi, Joan Anim-Addo, Velma Pollard and Carla Sassi (eds), Caribbean-Scottish Relations Colonial E Contemporary Inscriptions in History, Language \& Literature, London: Mango Publishing.

Bhabha, H. K. (1994), The Location of Culture, London and New York: Routledge.

Clifford, J. (2000), 'Taking identity politics seriously: "The Contradictory, Stony Ground ..."', in P. Gilroy, L. Grossberg and A. McRobbie (eds), Without Guarantees: In Honour of Stuart Hall, London: Verso, pp. 94-112.

Collins, Patricia Hill (1990), 'Othermothering', Black Feminist Thought: Knowledge, Consciousness and the Politics of Empowerment.

Frosh, Stephen (2007) Disintegrating Qualitative Research. Theory and Psychology, 17, 635-53.

Glissant, Edouard (1997), Poetics of Relation (trans. Betsy Wing), Ann Arbor: University of Michigan Press.

Gunaratnam, Y. (2003), Researching 'Race' and Ethnicity: Methods, Knowledge and Power, London: Sage Publications.

Haraway, D. (1988), 'Situated knowledges: The science question in feminism and the privilege of partial perspective', Feminist Studies, 14: 3, p. 575.

Lommel, A. (1966), Prehistoric and Primitive Man, London: McGraw-Hill.

Mulzac, Hugh (1963), A Star to Steer By, New York: International Publishers.

Roy, A. (2002), 'Come September', Tamilnation.org, http://tamilnation.co/intframe/roy/arundhati1. htm. (accessed 10 December 2012)

Riessman, C. (2005), 'Exporting ethics: A narrative about narrative research in South India', Health, 9: 4, pp. 473-90.

Sassi, Carla and van Heijnsbergen, Theo (forthcoming), Within and Without Empire: Scotland Across the (Post)colonial Borderline, Cambridge Scholars Publishing.

Schwartz, Joan M. and Cook, Terry (2002), 'Archives, records, and power: The making of modern memory', Archival Science, 2: 1, pp. 1-19.

Wengraf, T. (2001), Qualitative Research Interviewing. Biographic Narrative and Semi-Structured Method, London: Sage.

\section{Suggested citation}

Anim-Addo, J. and Gunaratnam, Y. (2012), 'Secrets and lies: Narrative methods at the limits of research', Journal of Writing in Creative Practice 5: 3, pp. 383-396, doi: 10.1386/jwcp.5.3.383_1 
10. Contact: Centre for Caribbean Studies, Goldsmiths, University of London, New Cross, London

11. SE14 6NW.

12. E-mail: j.anim-addo@gold.ac.uk

13.

14. Yasmin Gunaratnam is a Senior Lecturer in the Department of Sociology, Goldsmiths, University

15. of London. She is author of Researching Race and Ethnicity (Sage, 2003) and has jointly edited

16. Narratives and Stories in Health Care with David Oliviere (Oxford University Press, 2009). She is

17. currently completing a manuscript of creative non-fiction, Death and the Migrant for Bloomsbury

18. Academic in which she brings together her work on diasporic dying and intercultural care.

19. Contact : Department of Sociology, Goldsmiths, University of London, New Cross, London SE14

20. $6 \mathrm{NW}$.

21. E-mail: y.gunaratnam@gold.ac.uk

23. Joan Anim-Addo and Yasmin Gunaratnam has asserted their right under the Copyright, Designs

24. and Patents Act, 1988, to be identified as the author of this work in the format that was submitted

25. to Intellect Ltd. 